\title{
Influence of amplicon size on the polymerase chain reaction of Parvovirus B19 genome in formalin-fixed specimens
}

\author{
Influência do tamanho do amplicon na reação em cadeia da polimerase na deteç̧ão do genoma do PB19 em amostras \\ fixadas em formalina
}

Paulo Roberto Veiga Quemelo'; Benedito Antônio Lopes da Fonsecaa; Danielle Malta Lima'; Luiz Cesar Peres

key words

Polymerase chain reaction

Parvovirus B19

Amplification

\section{abstract}

The polymerase chain reaction (PCR) has provided diagnosis of archival material, but some fixation methods such as formalin damage DNA and, subsequently, affect PCR analysis, particularly paraffin-embedded tissues. PCR is known due to its high specificity and sensitivity, although some difficulties arise when formalinfixed and paraffin-embedded tissue is used. Not only does this occur due to protein cross-linking, which increases with longer fixation time, but it also happens due to the direct damage that formalin causes in the DNA itself. PCR was used to analyze placenta and fetal organs from 34 samples with suspected Parvovirus B19 infection. It was not possible to amplify Parvovirus B19 DNA using nested-PCR, probably due to the size of the amplicon generated with the first set of primers. We approached this problem by using only the second set of primers. Two out of 34 tissue samples $(5,9 \%)$ were positive by PCR. However, PCR performed on corresponding fetal organs was negative in one of the two. We also observed a negative relation between the thickness of the tissue fragment and the positivity of the samples. In conclusion, although PCR is highly specific and sensitive in fresh or ideally fixed material, a careful standardization of PCR assays is necessary when using formalin fixed paraffin-embedded tissues by applying primers that require smaller DNA fragments for amplification.
A reação em cadeia da polimerase ( $P C R$ ) tem fornecido diagnóstico de material de arquivo, mas alguns métodos de fixação, tais como formalina, provocam danos ao DNA e subsequentemente afetam sua análise, particularmente tecidos embebidos em parafina. A PCR é conhecida pela sua alta especificidade e sensibilidade, embora algumas dificuldades ocorram quando o material utilizado foi fixado em formalina e embebido em parafina. Isso não se deve somente pela formação de cross-linkings com proteínas, a qual aumenta com o maior tempo de fixação, mas também pelo dano direto que a formalina causa no DNA. PCR foi usada para analisar placenta e órgão fetais de 34 amostras com suspeita de infecção pelo Parvovírus B19 (PB19). Não foi possível amplificar o DNA do PB19 usando nested-PCR, provavelmente devido ao tamanho do amplicon gerado com o primeiro passo dos primers. Adequamos o problema utilizando somente o segundo par de primers e pudemos observar que das 34 amostras, duas eram positivas para PCR (5,9\%). Entretanto, a $P C R$ dos órgãos fetais foi negativa em um de dois casos. Observamos também uma relação negativa entre a espessura do corte dos materiais com a positividade das amostras. Em conclusão, embora a PCR seja altamente específica e sensivel em amostras a fresco ou idealmente fixadas, uma padronização cuidadosa para análise com a PCR é necessária quando se utiliza tecidos fixados em formalina e embebidos em parafina utilizando primers que requerem menor fragmento de DNA para a amplificação.

\section{unitermos}

Reação em cadeia da polimerase

Parvovírus B19

Amplicon

1. Post-graduate student, department of Pathology, Ribeirão Preto School of Medicine/ University of São Paulo (FMRP/USP).

2. Associate professor, MD, Ph.D., department of Internal Medicine, FMRP/USP.

3. Post-graduate student, department of Internal Medicine, FMRP/USP.

4. Associate Professor, MD, Ph.D., department of Pathology, FMRP/USP. 


\section{Introduction}

Parvovirus B19 (PB19) was identified in the serum of a healthy blood donor in 1975 by Cossart et al.(4). It is the only virus belonging to the Parvoviridae family that is pathogenic to humans, and has a worldwide distribution ${ }^{(1)}$. Although post-natal PB19 infection is usually mild, either completely asymptomatic or manifested by rash, fever, arthropathy, malaise or myalgia ${ }^{(2,17,22)}$, the disease may be life-threatening during fetal life. Vertical transmission, which occurs in over $30 \%$ of cases $^{(2,22)}$, may result in fetal hydrops or abortion ${ }^{(9,12,25)}$. The virus replicates in erythroid precursor cells ${ }^{(7,16,19)}$, resulting in anemia. More recently, it has been shown to infect cardiomyocytes ${ }^{(18)}$, which in association with anemia can induce heart failure and fetal hydrops. Histopathological and immunohistochemistry diagnosis of PB19 infection in formalin-fixed, paraffin-embedded tissues have been made ${ }^{(14,21,24)}$, but there are some drawbacks with these methods. Histological analysis of such tissues lacks a high degree of sensitivity and specificity. However, recently, a number of PCR protocols have been developed for amplifying PB19 DNA sequences in clinical and archival materials $(3,10,11)$. PCR is known to be a highly specific and sensitive DNA amplification method used widely in research, especially in the diagnosis of infectious diseases ${ }^{(10,}$ 15). However, formalin fixation may damage the DNA, due to the crosslinking of proteins ${ }^{(11)}$, and interfere with the amplification process. This is specially troublesome when long DNA regions are amplified, old paraffin blocks are used, or fixation time is over three days ${ }^{(8,11)}$. The present study is aimed at the PCR diagnosis of PB19 infection in formalin fixed and paraffin-embedded tissues from non-immune fetal hydrops or diffuse villous edema examined at the Ribeirão Preto School of Medicine, University Hospital, University of São Paulo (HC/FMRP/USP).

\section{Material and methods}

This study was approved by the Ethical Research Committee of the HC/FMRP/USP.

A total of 34 formalin-fixed, paraffin-embedded tissue samples were used, of which 26 were placentas from well-formed fetuses with nonimmune hydrops, and eight were tissue fragments obtained through curettage. The latter presented diffuse villous edema and few or no fetal tissues. The samples were selected from a collection at the Pathology Department of the HC/FMRP/USP and represented the suspected cases evaluated from january 1998 to december 2002. Phosphate-buffered saline was used as a negative control and a sample obtained from a child with a known acute PB19 infection was used as a positive control. As a control for DNA integrity in the PCR amplification reactions, the endogenous mammalian $\beta$-globin gene was also amplified with a pair of $\beta$-globin-specific oligonucleotide primers ${ }^{(6)}$.

Paraffin blocks were cut using a new clean disposable knife for each section, and collected into new, clean $1.5-\mathrm{ml}$ microtubes for PCR processing. Thickness of the histological sections tested were $30 \mu \mathrm{m}, 20 \mu \mathrm{m}, 10 \mu \mathrm{m}$ and $5 \mu \mathrm{m}$. Paraffin was removed by three xylene and two absolute ethanol washes followed by DNA extraction with Wizard ${ }^{\circledR}$ Genomic DNA Purification Kit (Promega Corporation, Madison, WI, USA), according to the manufacturer's protocol. DNA was quantified in a BECKMAN DU-600 spectrophotometer.

The DNA amplification was performed in a $50 \mu$ final volume containing $220 \mu \mathrm{M}$ of dNTPs and 20 pmol of sense primer (B19-1; CAA AAG CAT GTG GAG TGA GG) and 20 pmol of antisense primer (B19-2; CCT TAT AAT GGT GCT CTG GG). Initially, the outer primers (Patou et al., 1993; CTT TAG GTA TAG CCA ACT GG and ACA CTG AGT TTA CTA GTG GG) were tested, but due to the results described in the next section, only B19-1 and B19-2 were used throughout the experiments. The amplification was performed in a 35 cycle protocol consisting at $94^{\circ} \mathrm{C}$ for 5 $\min$ (one cycle); $94^{\circ} \mathrm{C}$ for $1 \mathrm{~min}, 50^{\circ} \mathrm{C}$ for $1.5 \mathrm{~min}, 72^{\circ} \mathrm{C}$ for $1 \mathrm{~min}$ ( 35 cycles), followed by a final step at $72^{\circ} \mathrm{C}$ for 5 min. The expected size of the amplicon obtained with this protocol was $104 \mathrm{bp}$.

Following amplification, the material was submitted to agarose gel electrophoresis, stained with ethidium bromide, and then photographed.

\section{Results}

From the 34 cases analyzed, recognizable fetuses were observed in 22. Of those, 12 were female and 10 were male. The fetuses were hydropic, but presented no other external or internal abnormality. In four cases there were only fragments of placenta and fetuses, and therefore, there was no possibility of macroscopic sex assignment. Only placenta fragments were represented in the remaining eight cases. Gestational age ranged from nine to 40 weeks, and fetal weight, from 34 to $1527 \mathrm{~g}$.

All of these samples were initially analyzed by a nested-PCR described by Patou et al. (1993) ${ }^{(19)}$, but no amplification was obtained. Due to these results, it was 
hypothesized that the size of the first generated amplicon was interfering with the results. Hence, the results described here refer to the use of the inner primers alone. PCR was also done on material obtained from histological sections of different thickness, as described in material and methods. Amplicons were generated only in the thinnest sections ( $5 \mu \mathrm{m}$ thick), probably due to incomplete DNA extraction, excessive residual protein or to degradation of DNA during paraffin removal from the thickest sections.

Of the 34 cases studied, two fragments of placenta were positive for PB19 PCR (5.9\%) (Figure). When PCR was applied to fetal organs (heart, lung, kidney and liver), only one case was positive, although the characteristic intranuclear viral inclusion was observed in the placenta and fetal organs of both cases. All tissues contained amplifiable $\beta$-globin DNA (data not shown). PCR results in the various tissues are compared in Table below.

\begin{tabular}{lcc} 
Table & $\begin{array}{l}\text { Results of the investigation for PB19 } \\
\text { infection by PCR in the various tissues }\end{array}$ \\
\hline Tissues & Case 1 & Case 2 \\
Placenta & PCR & PCR \\
Heart & + & + \\
Liver & + & - \\
Lungs & + & - \\
Kidneys & + & - \\
PCR: & + & -
\end{tabular}

PCR: polymerase chain reaction.

$\begin{array}{lllll}M & C & N & 1 & 2\end{array}$

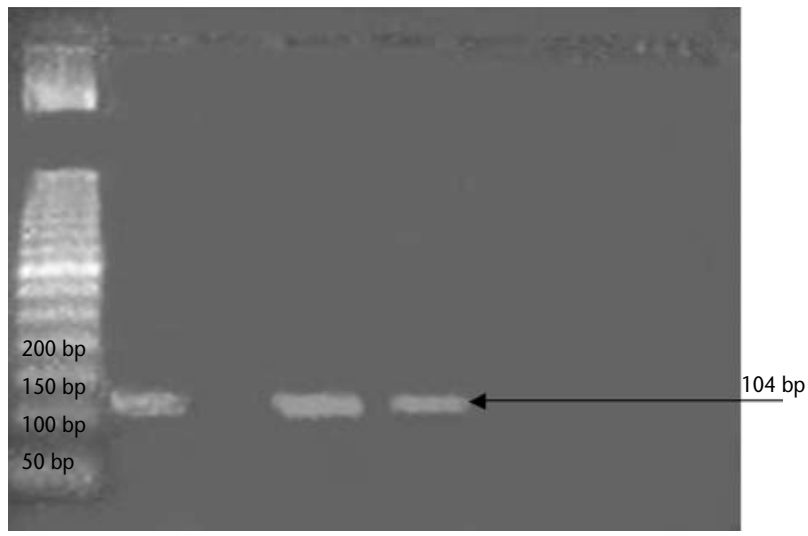

Figure - $P C R$ amplification of the two PB19 infected placentas. M: DNA ladder; $C$ : positive control; N: negative control; 1: case one; 2: case 2

\section{Discussion}

Infection with PB19 is common in the general population. The serological prevalence ranges from $75 \%{ }^{(22)}$ to over $90 \%{ }^{(17)}$ in adults aged 50 or older, and the infection usually presents as a mild self-limited disease ${ }^{(15)}$. The deleterious result of PB19 infection is seen when pregnant women are infected and the fetus becomes involved. PB19 replicates in red blood precursor cells $s^{(1,5,16)}$, leading to decreased production of these cells and, consequently, anemia and myocardial failure. In the present study, two out of 34 cases of non-immune hydrops fetalis were positive by PCR, resulting in a prevalence of $5.9 \%$, which is within the range of $4 \%$ to $16 \%$ reported in the literature ${ }^{(2,22)}$. Also, in accordance with the literature, the two positive cases were second trimester cases ${ }^{(22)}$. The peak in incidence of PB19 infection and consequent hydrops occurring in the second trimester is explained by the substantial increase in blood cell production and the decrease in fetal tolerance for anemia due to a small hematological reserve ${ }^{(5,21)}$. Therefore, the second trimester is usually the best moment for clinical diagnosis ${ }^{(15,21,24)}$, although with the advent of molecular diagnosis, peak incidence of PB19 infection has shifted to the end of the third trimester, probably due to the higher sensitivity of this technique ${ }^{(13,20,22)}$.

Formalin-fixed and paraffin-embedded tissue used for histological examination has been used frequently for DNA extraction in different protocols for PB19 detection ${ }^{(10,11)}$. The reported problems with PCR amplification for this type of material were also observed in the present study by the negative results obtained in the fetal organs of one of the cases, although it was positive in the placenta and nuclear viral inclusions were observed by light microscopy. The low percentage of PB19 DNA amplification may also be related to the type of samples used here. Formalin fixation may damage the DNA due to crosslinking with proteins which increases with the duration of fixation ${ }^{(11)}$. The reason why PCR was positive in the placenta and negative on other tissues might be associated either to a shorter fixation time as they are sent for analysis and processed in different ways and moments, to a higher sensitivity of PCR or to the deleterious effect of formalin-fixation by the organ tissues, or to a higher amount of PB19 DNA on the placenta.

In 1993, Patou et al. ${ }^{(19)}$ described a protocol to detect PB19 infections using a nested-PCR method where the first set of primers amplified a DNA fragment of $1.112 \mathrm{bp}$. After the first-round of amplification, the PCR product was subjected to a nested-PCR with a second set of primers (B19-1 and B19-2) to produce a 104 bp product. However, in our study it was not possible to amplify PB19 DNA with the nested PCR probably due to the formalin-fixation interference that may have induced DNA degradation 
and consequently preventing for amplification of the long DNA region flanked by the first set of primers ${ }^{(8,11)}$. We approached this problem through the use of the second set of primers only, since they amplify a much shorter DNA region. Using this approach we were able to amplify PB19 DNA from the two samples described before.

According to Greer et al. $(1995)^{(8)}$, there are four variables that determine the success of PCR in paraffin-embedded tissue: type of fixative used, duration of fixation, age of the paraffin block, and length of the DNA fragment to be amplified. We have found that fragment thickness is also important, since PB19 DNA was only amplified from $5 \mu \mathrm{m}$ thick sections, probably due to the amount of paraffin and proteins that are not completely eliminated in the thicker samples, and thereby interfering with both the extraction and amplification processes.

Finally, although PCR is more specific and sensitive in fresh or ideally fixed samples ${ }^{(22)}$, it undergoes a significant drop in these parameters when formalin-fixed and paraffin-embedded tissues are used. It is clear from our data that the smallest the fragment to be amplified the highest the chance of a PCR protocol to be successful. In our case, a nested-PCR was not as sensitive as the conventional PCR, probably due to the longer fragment that needs to be amplified on the first round of PCR amplification. PCR can be used for the diagnosis of PB19 infection in fixed tissues, but one has to be aware that a considerable percentage of negative results will be found when compared with fresh tissues. However, PCR will certainly help on the definition of selected PB19 cases where all others tests have been unclear concerning to a specific diagnosis.

\section{Acknowledgments}

Grant support: Coordenação de Aperfeiçoamento de Pessoal de Nível Superior (CAPES) and Fundação de Apoio ao Ensino, Pesquisa e Assistência do HC/FMRP/USP (FAEPA).

\section{References}

1. BROWN, K. E.; YOUNG, N. S. Parvovirus B19 in human disease. Annu Rev Med, v. 48, p. 59-67, 1997.

2. BROWN, T. et al. Intrauterine parvovirus infection associated with hydrops fetalis. The Lancet, v. 2, p. 1033-4, 1984

3. CAWKWELL, L.; QUIRKE, P. Direct multiplex amplification DNA from a formalin fixed, paraffin wax embedded tissue section. J Clin Mol Pathol, v. 53, p. 51-2, 2000.

4. COSSART, Y. E. et al. Parvovirus-like particles in human sera. The Lancet, v. 11, p. 72-3, 1975.

5. ENDERS, G.; BIBER, M. Parvovirus B19 infections in pregnancy. Behring Inst Mitt, v. 85, p. 74-8, 1990.

6. FERRE, F.; GARDUMO, F. Detection of human Papillomavirus types 6/11/,16 and 18 using PCR. Cancer Cells, v. 7 , p. $215-8,1989$.

7. GARCIA, R. C. N. C. Parvoviriade. In: Oliveira, L. H. S. Virologia humana. 1. ed. Rio de Janeiro: Cultura Médica, 1994.

8. GREER, C. E.; WHEELER, C. M.; MANOS, M. M. PCR amplification from paraffin-embedded tissues: sample preparation and the effects of fixation. In: Dieffenbach, C. W; Dveksler, G. S., PCR Primer: a laboratory manual. Cold Spring Harbor: Cold Spring Harbor Laboratory Press, 1995.
9. HEEGAARD, E. D. et al. Congenital anemia caused by Parvovirus B19 infection. Pediatr Infect Dis J, v. 19, p.1216-8, 2000.

10. JORDAN, J. A. Identification of human parvovírus B19 infection in idiopathic nonimmune hydrops fetalis. Am J Obstet Gynecol, v. 174, p. 37-41, 1996.

11. KARLSEN, F. et al. Modifications of human and viral deoxyribonucleic acid by formaldehyde fixation. $J$ Vet Diagn Invest, v. 71, p. 604-11, 1994.

12. KNOLL, A. et al. Parvovirus B19 infection in pregnancy: quantitative viral DNA analysis using a kinetic fluorescence detection system (TaqMan PCR). J Med Virol, v. 67, p. 259-66, 2002.

13. MA, T. S. Applications and limitations of polymerase chain reaction amplification. CHEST, v. 108, p. 1393-404, 1995.

14. MOREY, A. L. et al. Immunohistological detection of human Parvovirus B19 in formalin-fixed, paraffin-embedded tissues. J Pathol, v. 166, p. 105-8, 1992.

15. MUSIANE, M. et al. Parvovirus B19 clearance from peripheral blood after acute infection. J Infect Dis, v. 172, p. 1360-3, 1995.

16. MUZYCZKA, N.; BERNS, K. I. Parvoviridae: The viruses and their replication. In: KNIPE D. M. Virology, 4th ed. Philadelphia: Lippincott Williams \& Wilkins, 2001. 
17. NASCIMENTO, J. P. et al. The prevalence of antibody to human parvovirus B19 in Rio de Janeiro, Brazil. Rev Inst Med Trop Sao Paulo, v. 32, p. 41-5, 1990.

18. O'MALLEY, A. et al. Parvovirus Infects cardiac myocytes in hydrops fetalis. Pediatr Dev Pathol, v. 6, p. 414-20, 2003.

19. PATOU, G. et al. Characterization of a nested polymerase chain reaction assay for detection of Parvovirus B19. J Clin Microbiol, v. 31, p. 540-6, 1993.

20. ROGERS, B. B. et al. Detection of human parvovirus B19 in early spontaneous abortuses using serology, histology, electron microscopy, in situ hybridization, an the polymerase chain reaction. Obstet Gyneco, v. 81, p. 402-8, 1993
21. TOROK, T. J. Parvovirus B19 and human disease. Adv Intern Med, v. 37, p. 431-55, 1992.

22. TOLFVENSTAN, T. et al. Frequency of human Parvovirus B19 infection in intrauterine fetal death. The Lancet, v. 357, p.1494-7, 2001.

23. VOGEL, H. et al. Congenital Parvovirus infection. Pediatr Pathol Lab Med, v. 7, p. 903-12, 1997.

24. WRIGHT, C.; HINCHLIFFE, S.A.; TAYLOR, C. Fetal Pathology in Intrauterine death due to parvovirus B19 Infection. $\mathrm{Br}$ J Obstet Gynaecol, v. 103, p.133-6, 1996.

25. ZAKZEWSKA, K. et al. Persistence of Parvovirus B19 DNA in Synovium of patients with haemophilic arthritis. J Med Virol, v. 65, p. 402-7, 2001. 